\title{
The Impact of the Russian-Ukrainian Military Conflict on Religious Life in Ukraine
}

\section{Instead of an introduction: \\ The religious situation in Ukraine before the conflict in Eastern Ukraine}

After the collapse of the Soviet Union, Ukraine and Russia established two different approaches to developing relations between church and state. The choice of these approaches was based on the different historical and cultural traditions of both countries and the peculiarities of their religious maps.

The Ukrainian model of church-state relations presupposes the separation of church and state. The American sociologist of religion José Casanova compares the Ukrainian model of church-state relations to the system of American denominational religious pluralism ${ }^{1}$, which is often called the great American religious invention $^{2}$. This system implies the equality of all religions before the constitution and ensures their development on the basis of free competition. The Ukrainian religious studies scholar and president of the Ukrainian Association of Religious Freedom Victor Yelensky identifies four main reasons for this situation ${ }^{3}$. First of all, he writes about the balance that emerged between religious institutions in Ukraine after 1991 (after the declaration of independence of Ukraine). None of the Ukrainian churches has a dominant position in more than two-thirds of the oblasts of Ukraine. Due to the presence of multiple centers of power, none of the

1 J. Casanova, Between Nation and Civil Society: Ethnolinguistic and Religious Pluralism in Independent Ukraine, [in:] Democratic Civility: The History and Cross-Cultural Possibility of a Modern Political Ideal, ed. by R. Hefner, New Brunswick, NJ 1998, pp. 215-219, At: http:// repository.berkleycenter.georgetown.edu/980201CasanovaBetweenNationCivilSocietyEthnolinguist icReligiousPluralismIndependentUkraine.pdf (15.05.2015).

2 S. E. Mead, Denominationalism: The Shape of Protestantism in America, "Church History", 1954, vol. 23, nr. 4, pp. 291-320; A. M. Greeley, The Denominational Society: A Sociological Approach to Religion in America, Glenview, IL 1972, 266 p.

3 V. Yelensky, Religion and Human Rights: The Case of Ukraine, [in:] Religion and Human Rights. An International Perspective, ed. by H.-G. Ziebertz and G. Črpić, Cham 2015, pp. 199-200. 
religious organizations has a dominant position and all of them are interested in maintaining high legal standards of religious freedom. Second, religion is not the key element of Ukrainian statehood. The religious affiliation of Ukrainians has no direct correlation with their national identity ${ }^{4}$. Third, thanks to a significant degree of separation of national and religious issues, a high level of religious freedom has never been a threat to the positions of power. Finally, the fourth reason, according to the author, is the high level of tolerance towards people of other religions that developed during the history of Ukraine.

The first years after gaining independence were very challenging for Ukraine and the Ukrainian faithful: the dissent of the Ukrainian Orthodoxy, the return of the Ukrainian Greek Catholic Church (UGCC) after being forced underground during the Soviet period, revival of the Ukrainian Autocephalous Orthodox Church (UAOC), and the emergence of a number of foreign missionaries, caused a series of religious conflicts, primarily over church buildings and believers. The situation stabilised in the early 2000s. In fact, in the first decade of the new millennium the churches faced a number of issues relating to the restitution of church property; expansion of the presence of religious organizations in the public sphere; development of an important social doctrine, an extension of believers' religiosity (in church's term - "votserkovlennia"); development of dialogue and cooperation with other churches, etc. However, the threat of direct religious conflict that was real in 1990s disappeared. Good evidence of this is the high level of religious freedom, registered by many international organizations. For example, according to the Pew Research Center, the "Religious Restriction Index Scores" in Ukraine in 2007 was $2.6^{5}$ out of 9 (the smaller the number, the higher the level of religious freedom; the average number for Europe was 2.4).

Things began to change for the worse after Victor Yanukovych became the president of Ukraine. In 2011, the Religious Restriction Index reached 3.9, and in 2012 it was at the level of $4.4^{6}$. The deterioration of religious freedom was noticed even by average Ukrainians. In 2010, according to the Razumkov Center only $29.4 \%$ of Ukrainians believed that the government treated equally all religious organizations, whereas $35.6 \%$ were convinced that the government gave some preferences to certain churches or church$^{7}$.

4 For more on that subject, see: V. Elenskii, Ukrainian Orthodoxy and the Ukrainian Project. The Churches and "Unforeseen Statehood" in the Age of Religious Revival, "Russian Politics and Law", 2014, vol. 52, issue 4, pp. 7-33.

5 Pew Research Center, January 2014, “Religious Hostilities Reach Six-Year High", p. 65, At: http://www.pewforum.org/files/2014/01/RestrictionsV-full-report.pdf (15.05.2015).

6 Ibidem.

7 Tsentr Razumkova, Lystopad 2010, “Z yakoyu otsinkoyu stavlennya derzhavnoyi vlady do Tserkov v Ukrayini Vy zhodni naybil'shoyu miroyu?" [What government attitude to Churches in Ukraine do you accept?]. At: http://www.uceps.org/ukr/poll.php?poll_id=689 (15.05.2015). 
In 2009, after Patriarch Kirill (Gundiaev) came to power he started to promote the doctrine of a "Russian World". This new policy of patriarchy triggered the activation of pro-Russian forces in the Ukrainian Orthodox Church (Moscow Patriarchate). The first Patriarch's speech on that subject resulted in a standstill of dialogue between the UOC (MP) and UOC-KP, which began in September 2009. The Patriarch initiated the reform of the Statute of the Russian Orthodox Church (ROC) which led to significant restriction of UOC (MP) liberties that were guaranteed by the Tomos of the Patriarch Alexei II (Ridiger) in 1990. These innovations caused concern and raging debate in the Ukrainian religious environment. Another reason for concern was the attempt of the pro-Russian wing of the UOC (MP) to seize power during the illness of Metropolitan Volodymyr (Sabodan), who took a moderate pro-Ukrainian position.

Attempts to consolidate the "special status" of the representatives of one church were made at the legislative level. The point at issue is the attempt of the party in power to inscribe into law the "Declaration on the dignity, freedom and human rights" of the Russian Orthodox Church. The document insisted on the connection between human dignity, morality, and human rights. According to the authors of the bill, the government had to abandon equal treatment of all religious organizations and build relationships with them "depending on their size, level of their conformism with the country or region, their contribution to the history and culture, their civic position"s (art. 10). The language of law could not only have different interpretations, it conflicted with basic international documents on human rights.

That was the general situation on the eve of massive protests in Kiev in late November 2013, which later became known as the Revolution of Dignity or Euromaidan. The participation of churches in these events was described in many detailed researches9. In our case, it is important to note that despite all internal and external pressures, religious organizations did maintain peace and avoid speculation on religious issues.

\section{"Parade of conversions" and its causes}

With the beginning of military operations in Eastern Ukraine, the so-called "parade of conversions" started in different regions (oblasts) of the state. Dozens

8 Proekt Deklaratsiyi pro hidnist, svobodu i prava liudyny [The Draft of Declaration on Dignity, Freedom and Human Rights], Verkhovna Rada Ukrainy, 2010, s. 4. At: http://w1.c1.rada.gov.ua/ pls/zweb2/webproc34?id=\&pf3511=38408\&pf35401=171219 (15.05.2015).

9 For example, see: Maydan i Tserkva: Khronika podiy ta ekspertna otsinka [Maidan and the Church: Chronicle of Events and Expert Evaluation], red. L. Fylypovych, O. Horkusha, Kyiv 2015, 650 s.; R. Lunkin, The Ukrainian Revolution and the Christian Churches, "East-West Ministry", 2014, Report 22, no. 3, pp. 1-6. 
of parishes of the UOC (MP) expressed their desire to change religious affiliation and move to the UOC-KP. The geography of those conversions was very broad: from Volyn, Rivne, Ternopil, and Bukovyna (Western Ukraine), to Kiev, Vinnytsia (Central Ukraine), and the Kherson regions (Southern Ukraine). In some cases $(5-7)^{10}$, parishes changed religious affiliation together with parish priests, in other cases there flared up some serious conflicts over church buildings and other property.

According to the statements of some converted believers, the main reasons for conversion were the politicization of religious sermons and the refusal of some priests to perform funeral service for activists of Euromaidan and Ukrainian soldiers who died in the ATO (Anti-terrorist operation zone).

After the first conversions there appeared several open letters to the current head of the UOC (MP) Metropolitan Onufriy (Berezovskyi). These letters were written by regular parishioners and priests and contained deep concern about the silence of the church at the time of the aggressive war against Ukraine, about current church policy and its future. "We, the clergy and parishioners of the UOC, are writing to you at the current difficult time not with anger and indignation, but with deep pain and concern about the holy Orthodox Church. We are not nationalists and do not aim for union with KP [UOC-KP], we are gradually losing parishes, now we have nothing to lose and that is why, frankly speaking, without choosing words, we have to tell you straight: Your silence and tacit support of the policy of Patriarchate is the main reason for the split in the UOC" ${ }^{11}$, said one of the letters.

The faithful point out a few aspects in church life, which provoke misunderstanding and concern. They include: (1) the lack of a clear church position on the conflict, (2) absence of response to the speeches and actions of some priests, who promote "ideologemes of the Russian political Orthodoxy"12, support terrorists and even take part in their criminal activity ${ }^{13}$, (3) the lack of reaction to the

10 Predsedatel departamenta po delam religiy ministerstva kultury Ukrainy Andrey Yurash o svoyei novoi dolzhnosti, yazykovoi i religioznoi politike, izmeneniyakh v UPTS MP, situatsii v Krymu $i$ "DNR" [Chairman of the Department of Religious Affairs of the Ministry of Culture of Ukraine Andriy Yurash on his new role, linguistic and religious policies, changes in the UOC MP, the situation in Crimea and "DPR"], Besedoval Vladimir Oyvin, "Portal-credo.ru". http://www.portalcredo.ru:12000/site/?act=news\&id=111867 (15.05.2015).

11 Zvernennya hromady tserkvy Iverskoyi Bozhoyi Materi v seli Kruholets Ternopilskoyi yeparkhiyi UPTS (Moskovskoho Patriarkhatu) do Predstoyatelya UPTS mytropolyta Onufriya [Appeal of the Community of the Church of the Iberian Icon of the Mother of God in the village of Kruholets in Ternopil Eparchy (Moscow Patriarchate) to the Primate of the Ukrainian Orthodox Church Metropolitan Onuphrius], http://www.religion.in.ua/news/ukrainian_news//28129-mi-svyashhenikiupc-opinilisya-mizh-gorem-svogo-narodu-i-vorozhoyu-poziciyeyu-patriarxiyi-ternopilska-gromada -upc-napisala-vidkrite-zvernennya-mitropolitu-onu (15.05.2015).

12 "Political Orthodoxy" was officially condemned by UOC (MP) in 2007.

13 Vidkrytyy lyst Predstoyatelyu UPTS mytropolytu Onufriyu vid hromady Dymytriyivskoho 
spread of false information about the situation in Eastern Ukraine (attempts to represent Russian aggression as a struggle of "uniates" and "schismatics" against canonical Orthodoxy; the church rewarding journalists who disseminate false information, etc.).

According to the authors of these letters, the most difficult to accept is the position of Patriarch Kirill (Gundyaev). "It is sad to realize, but it is impossible to listen to Patriarch without fear for the future of our nation and our Church. His Holiness went too far in His political activities, just as the "Orthodox army of Novorossiya" penetrated into the territory of Ukraine" 14 . The Patriarch's doctrine of the "Russian World" has not only become the basis for Russian neo-imperial ideology, it is used by Russian authorities to justify intervention in the territory of Ukraine.

A flurry of criticism was also provoked by the Patriarch's letters ${ }^{15}$ to the Primates of local Orthodox Churches, the UN and other international organizations, which were published on the Day of Independence of Ukraine. These documents described the events in Eastern Ukraine as a "fratricidal civil war" led by "Greek Catholics" and "splitters" against the "canonical Ukrainian Orthodox Church". The Patriarch stated that the purpose of armed confrontation was the "eradication of Orthodoxy in Ukraine" and provided information about the mistreatment (search and interrogations) of Orthodox priests suspected of collaboration with terrorists. The Patriarch did not mention the seizure of numerous churches and the murders of Protestant pastors, committed by the so-called "Russian Orthodox army" a few weeks before that.

According to the reports of human rights activists, the vast majority of religious organizations were prohibited, except for the UOC (MP) ${ }^{16}$. The most victimized communities in the occupied territories were Evangelical Christians (Pentecostals, Baptists, Adventists, Charismatics, etc.), Greek- and Roman-Catholics, and representatives of the alternative Orthodoxy (UPC-KP).

The rhetoric of the Patriarch and representatives of the Patriarchate led to a rapid loss of credibility of the church's leaders. A number of priests who are

khramu sela Vyshniv [Open letter of the community of the church of St. Dmytriy in the village of Vyshniv to Metropolitan Onuphrius]. http://vyshniv.blogspot.com/2014/10/blog-post_8.html (15.05.2015).

14 Zvernennya hromady tserkvy Iverskoyi Bozhoyi Materi..., op. cit.

15 Obrashcheniye Svyateyshego Patriarkha Kirilla k Predstoyatelyam Pomestnykh Pravoslavnykh Tserkvey v svyazi s situatsiyey na Ukraine (24 avgusta 2014). [Address of His Holiness Patriarch Kirill to the Primates of Autocephalous Orthodox Churches on the situation in Ukraine (August 24, 2014)]. At: http://www.patriarchia.ru/db/text/3704024.html (15.05.2015).

16 Kongress natsional'nykh obshchin Ukrainy, 2014, "Ksenofobiya v Ukraine v 2014 g. na fone revolyutsii $i$ interventsii: Informatsionno-analiticheskiy doklad po rezultatam monitoringa" [Xenophobia in Ukraine in 2014 amid revolution and intervention: Information-analytical report on the monitoring results], p. 65. At: http://eajc.org/data//file/Xenophobia_in_Ukraine_2014.pdf (15.05.2015). 
still a part of the UOC declared a refusal to mention the Patriarch's name during worship services.

The changes of the parishes' administrative subordination have caused a series of disputes and accusations of the "seizure" of parishes. At the end of 2014 the Department of Religious Affairs facilitated the establishment of a temporary working group on current religious conflicts. The group was made up of not only official representatives of both churches, but also of religious experts and representatives of law enforcement agencies. In a number of cases, court proceedings are in progress.

\section{Changes of religious self-identification}

Despite severe criticism, in Ukraine there are about 30 communities which have decided to change their subordination. This number is imperceptible on a nationwide scale. It doesn't even account for one percent of the Ukrainian religious network. At the same time, the changes of believers' self-identification have been more significant. They were fixed by sociologists at the beginning of this year.

At the beginning of spring, two well-known sociological organizations presented the results of parallel studies that elicited the same trends. The first ${ }^{17}$ study was represented by the Ilko Kucheriv Democratic Initiatives Foundation (IKDIF). It included 4,413 respondents. The second survey ${ }^{18}$ was a joint project of four sociological companies: the Center for Social and Marketing Research SOCIS, Sociological Group "Rating", the Razumkov Center, and the Kiev International Institute of Sociology. This study can be called one of the largest Ukrainian religious surveys. 25,000 respondents were interviewed. This study is representative of all oblasts of Ukraine.

First of all, the changes concerned the question of belonging to religious organizations and distribution of the faithful in different Eastern Orthodox churches. According to the published data, most Ukrainians (38\%, according to IKDIF $44 \%$ ) now refer themselves to the UOC-KP. The share of supporters of the UOC (MP) has decreased to about 1/5 of the Eastern Orthodox Christians in

17 Mizhnarodnyy tsentr perspektyvnykh doslidzhen', Fond Demokratychni initsiatyvy imeni Il'ka Kucheriva, Kviten' 2015, 'Tserkva v Ukrayini: element roz'yednannya, ob 'yednannya chy myrotvorchosti? Rezul'taty zahal'nonatsional'noho sotsiolohichnoho opytuvannya, provedenoho u ramkakh proektu "Natsional'nyy dialoh" [The Church in Ukraine: an element of disintegration, integration, or peacemaking? Results of national poll conducted in terms of "Initiating the Participatory National Dialogue in Ukraine" project". At: http://icps.com.ua/assets/uploads/files/national_ dialogue_opinion_poll_3_part_ua.pdf (15.05.2015).

18 Tsentr sotsial'nykh ta marketynhovykh doslidzhen' SOCIS, and et al., Kviten' 2015, "Relihiyni vpodobannya naselennya Ukrayiny" [Religious preferences of the population of Ukraine]. At: http://www.ratinggroup.com.ua/upload/files/RG_religion_report_042015.2.pdf (15.05.2015). 
Ukraine and accounts for $19.6 \%$ (according to IKDIF, 20.8\%). This division reflects a paradox between the self-identification of believers and the institutional development of churches. According to official state statistics, on January 1, 2015 , the number of registered ${ }^{19}$ communities of the UOC (MP) was approximately 2.5 times bigger than the number of communities of the UOC-KP ${ }^{20}$.

On the one hand, issues of religiosity and actual (not just formal) affiliation to a religious community have been stumbling blocks for sociologists of religion since the middle of the last century. On the other hand, the simple registration procedure of religious communities in Ukraine in totality together with the voluntarist principle of belonging to parishes in cities makes it virtually impossible to find a clear correlation between the number of parishes and the number of parishioners.

However, even those facts are unlikely to fully explain such a big difference. Those numbers may to some extent reflect not only the religious, but also the cultural and civilizational choices of respondents. Sociologists fixed that phenomenon a long time ago, but it was almost an unnoticeable trend.

The religious map has undergone the biggest changes in the southern and eastern regions of the country. First of all, there has been a dramatic increase in the number of people identifying themselves as "just Eastern Orthodox" and rejecting any institutional affiliation. According to the data of the Center for Social and Marketing Research SOCIS et al. in Donetsk oblast, their number accounts for 50\% of those who call themselves Eastern Orthodox; in Luhansk region the number is $47 \%$, in Odessa $-46 \%$, in Mykolaiv $-61 \%$, in Kharkiv $60 \%$, in Zaporizhia - 54\%, in Kirovohrad - 64\%, in Dnipropetrovsk - 54\%. The total number of "just Eastern Orthodox" in Ukraine is about $40 \%$ of all people who identify themselves with Eastern Orthodoxy ${ }^{21}$.

Second, in some oblasts there is a significant increase in the proportion of people who do not belong to any religion (6.1\% in total) or consider themselves atheists $(9.5 \%)$. The most atheistic regions of Ukraine are Kharkiv (18.6\%) and Donetsk $(17.5 \%)^{22}$.

Third, the number of supporters of the UOC (MP) has reduced significantly. This church continues to dominate only in Donetsk (47\%), Luhansk (35\%), and Odessa $(31 \%)$ oblasts. On the nationwide scale there are only four of these oblasts. Chernivtsi region (53\%) is the fourth oblast ${ }^{23}$.

\footnotetext{
19 According to the Ukrainian law, state registration of religious communities is not obligatory.

20 Ministerstvo kul'tury Ukrayiny, 2015, "Relihiyni orhanizatsiyi v Ukrayini (stanom na 1 sichnya 2015 r.)” [Religious Organizations in Ukraine (on January 1, 2015)]. http://risu.org.ua/ua/index/ resourses/statistics/ukr2015/60129/

21 Tsentr sotsial'nykh ta marketynhovykh doslidzhen' SOCIS..., op. cit., p. 7.

22 Mizhnarodnyy tsentr perspektyvnykh doslidzhen'..., op. cit., p. 3.

23 Tsentr sotsial'nykh ta marketynhovykh doslidzhen' SOCIS..., op. cit., p. 7.
} 
Fourth, the positions of the UOC-KP have strengthened. This church is beginning to dominate in most oblasts as well as in the east and south of the country (in both cases, it accounts for about one-third of the total number of Eastern Orthodox believers) ${ }^{24}$.

Another remarkable Ukrainian religious trend is the loss of wide public trust. After the collapse of the Soviet Union, the church was viewed as a "natural defender of human rights" 25 and the level of public confidence in it was traditionally high. In fact the church was the first in the list of institutions which were trusted. In 24 years of Ukrainian independence, the church has only once lost public credibility (after the Orange Revolution). Recent polls show that there is a similar situation now. At the end of 2014, the most trusted organisations in Ukraine were the volunteer organizations and the volunteer battalions ${ }^{26}$. In fact, every fourth Ukrainian (24.5\%) completely trusts the volunteer battalions. Though the church managed to take a rather high third place $(19.3 \%$ of Ukrainians trust it completely), this trust gradually decreases as we move to the East. In the West of the state this number is traditionally the highest and accounts for $35.3 \%$, in the Centre it is $16.8 \%$, and in the East $-9.8 \%$. The lowest rate of confidence in the church is in Kharkiv region $-3.2 \%{ }^{27}$.

The identification of reasons for refusal of institutional affiliation and changes in confessional self-identification clearly needs further qualitative research. However, today the social consolidation of the West and East of Ukraine is becoming much stronger (first of all, because of Russian aggression), and the level of rejection of institutional religiosity is increasing with the degree of pro-Russian spirit in the church.

\section{The search for new forms of unity and cooperation}

Another interesting fact concerns the idea of creating a single Local Autocephalous Orthodox Church. The number of supporters of this idea is twice the number of its opponents ( $28 \%$ vs. $14 \%)$, but more than half of respondents $(58 \%)$ are either indifferent to this idea $(34.8 \%)$ or have no answer to this question $(23.5 \%)^{28}$. In fact, refusal of the idea of creating a unified church means social legitimization of religious pluralism, which has been established in

\footnotetext{
24 Ibidem.

25 V. Yelensky, Religion and Human Rights..., op. cit., p. 195.

26 ZN.UA, Kyyivs'kyy mizhnarodnyy instytut sotsiolohiyi, "Mneniya i vzglyady naseleniya Ukrainy: Dekabr 2014 goda" [The views and opinions of the Ukrainian population: December 2014]. At: http://opros2014.zn.ua/authority

27 Ibidem.

28 Mizhnarodnyy tsentr perspektyvnykh doslidzhen'..., op. cit., p. 7.
} 
Ukraine. Despite all the drama of the church split, at the critical moment the situation appeared to be positive to regular believers. They now have a wide range of ways to satisfy their religious needs. In addition to religious tradition, people's choice of parish more often depends on not only the territorial principle, but on relations between parishioners and priest, on the possibility to participate in the social activities of the church, or even on some specific cultural and ideological preferences.

Canonical status ("canonical"/"non-canonical"), which is often appealed to by representatives of the Moscow Patriarchate, has become a strong argument for only 1/10 of Ukrainian Eastern Orthodox believers. Only 10\% of respondents characterised the UOC (MP) as "the only canonical church". At the same time, just 7\% of Ukrainians called the UOC-KP "non-canonical" ("schismatic") 29.

In addition to the fact that Ukrainians demonstrate indifference to the idea of creating a single Local Autocephalous Orthodox Church, the events of 20132015 intensified the dialogue on the institutional unification of pro-Ukrainian churches. The first step in that direction was the so-called Rivne memorandum ${ }^{30}$ - a joint document, developed by representatives of four Churches (UOC (MP), UOC-KP, UAOC and UGCC) on state unity and unification of the Ukrainian Orthodox Churches. Though the document wasn't approved by official church leaders, and most signers have withdrawn their signatures, it was a good illustration of public sentiment.

One more dialogue was initiated by the UOAC, which is the smallest in number among the above mentioned churches. In recent years it has faced many challenges: from the separation of some of its parts to the change of church leadership (the previous head of the church died last year). At the beginning of April, the locum tenens of the patriarchal see of the UAOC Metropolitan Macarius (Maletich) announced his readiness to start a dialogue on administrative unification with the UOC-KP. There are no dogmatic differences between those two churches; their division was caused mainly by past misunderstandings and personal offences. Both churches moved a long way to this decision and underwent significant internal changes. After a new round of dialogue, a unification council was appointed in September 2015 ${ }^{31}$ (art. 7).

29 Ibidem, p. 4-5.

30 Memorandum pro yedynu Ukrayinu ta yedynu Ukrayinsku Pomisnu Pravoslavnu Tserkvu [Memorandum on the unified Ukraine and the united Ukrainian Autocephalous Orthodox Church]. http://orthodoxy.org.ua/data/na-rivnenshchini-pidpisali-memorandum-pro-iedinu-ukrayinu-ta-iedin u-ukrayinsku-pomisnu

31 Ukrayins'ka Pravoslavna Tserkva Kyyivs'koho Patriarkhatu, Ukrayins'ka Avtokefal'na Pravoslavna Tserkva, Cherven' 8, 2015, "Pidsumkove rishennya spil'noho zasidannya Komisiy dlya vedennya dialohu" [Final decision of the meeting of the Committees for dialogue]. At: http://www.ce rkva.info/uk/publications/articles/6958-rishennia.html (20.06.2015). 
Another aspect of religious life that was affected by the war in the East of Ukraine was the intensification of churches' social activities. According to official UN data the war has already taken at least 6362 lives (+ about 1300 people are considered to be missing); more than 15775 people have been injured and maimed ${ }^{32}, 1358000$ displaced $^{33}$. Moreover, those figures are only the official statistics. The representatives of organizations collecting the data report that the actual figures are much higher, primarily among the civilian population (because of a great number of unreported deaths and missing). Despite the announced ceasefire, the number of injuries and deaths is still increasing.

In this situation society needs broad social mobilization in which churches should actively participate. After all, they are able to accumulate substantial financial resources. Besides, they have an extensive institutional network.

The most popular forms of churches' social activities are: provision pf humanitarian aid, help with temporary accommodation for internally displaced persons, assistance with reconstruction of liberated territories, provision of spiritual and psychological assistance to soldiers and survivors from the occupied territories, etc.

One of the most productive platforms for church cooperation and coordination of activities in the new conditions became the All-Ukrainian Council of Churches and Religious Organizations. This organization was founded in 1996 as an advisory body for effective cooperation between state and religious organizations. Today it includes 18 religious organizations that bring together more than $90 \%$ of believers. AUCCRO has become the exponent of the consolidated position of Ukrainian churches on a number of issues: the situation in the East and readiness of the religious organizations to assist in the process of peace making, the role and responsibility of mass media, duty of homeland defense, condemnation of attempts to preach religious hatred, condemnation of separatism, support of volunteer activities, and others.

\section{Legal challenges}

The events of the last year and a half have not only significantly changed the life of religious communities in Ukraine, but also put on the agenda of our country several challenges that should be solved.

32 Office of the United Nations High Commissioner for Human Rights. "Report on the human rights situation in Ukraine (16 February to 15 May 2015)", p. 4. At: http://www.ohchr.org/Docu ments/Countries/UA/10thOHCHRreportUkraine.pdf (20.06.2015).

33 The UN Refugee Agency, June 2015, “Ukraine: Internally Displaced People” (June 22, 2015). At: http://unhcr.org.ua/attachments/article/1244/map47.jpg (23.06.2015). 
The first challenge is the return of high standards of religious freedom. The war adds the risk of new religious conflicts. The prevention of conflicts on religious grounds, the increase of state assistance in settlement or at least minimization of the current conflicts that appeared after the "parade of conversions", are on the agenda of the state. Analyzing the first court decisions in these cases, the Ukrainian religious studies scholar and former head of the State Committee on Nationalities and Religions Oleksandr Sagan points ${ }^{34}$ to the necessity of developing practical mechanisms to ensure the right of religious communities to freely express or change their religious affiliation. The provision of this right is the responsibility of the state, which is written in the Constitution.

The problems with religious freedom in the annexed Crimea and religious persecution in the occupied parts of Donetsk and Luhansk oblasts are major challenges. The nature of restrictions in both cases is different. After the annexation of Crimea, local religious organizations were forced to re-register in accordance with Russian law, which is harsher compared to the Ukrainian. First, according to Ukrainian legislation, the registration of religious communities is voluntary. Using Ukrainian law, 674 out of 2,083 religious communities of Crimea acted without state registration. Now all of them are obliged to register.

Second, the compulsory conditions for re-registration are either entry into already existing organizations and centers of the Russian Federation, or passage of special state religion expertise. Third, according to Russian law, only Russian citizens can establish religious organizations with corporate status. The representatives of churches should either renounce their citizenship or abandon the right to establish religious organizations with corporation. The re-registration should be performed by January 1, 2015. For now only 12 religious communities and 2 religious groups have managed to pass the necessary procedure. This is less than $1 \%$ of the religious organizations in Crimea. At the beginning of the year the term of re-registration was extended until January 1, 2016.

In addition to legal pressure, there are other violations fixed by believers and human rights activists ${ }^{35}$. They are seizure of church buildings, detention of priests, interrogation and threats to clerics, financial pressure ${ }^{36}$ on some communities, and so on. This is just a short list of the violations. Despite these

34 O. Sahan, Relihiyni hromady peretvoryly na "prypysnykh kripakiv" [Religious communities have turned into "bonded serfs"], 2015. At: http://risu.org.ua/ua/index/expert_thought/comments/ 59594/

35 United States Commission on International Religious Freedom. Annual Report 2015, pp. 180 181. At: http://www.uscirf.gov/sites/default/files/USCIRF\%20Annual\%20Report\%202015\%20(2) .pdf (20.06.2015).

36 M. Vasin, Donbas i Krym: novi vyklyky dlya relihiynoyi svobody. Pidsumky roku [Donbass and Crimea: new challenges for religious freedom. Results of the year]. At: http://risu.org.ua/ua/ index/expert_thought//analytic//58577// 
violations, Ukraine has no other way to influence the situation on the peninsula, except for drawing the attention of international institutions to the problem.

The situation in the occupied parts of Donetsk and Luhansk regions is even worse. In May 2014 the terrorists promulgated a document entitled "The Constitution of the Donetsk People's Republic" ${ }^{37}$, which contained several articles on religion. First of all, it proclaims that the "dominant" religion in these lands is the "Orthodox faith (Christian Catholic Faith of Eastern Tradition) embraced by the Russian Orthodox Church (Moscow Patriarchate)"38 (Article 9). Despite the formal prohibition of discrimination on religious grounds (Article 13), the organization recognizes the duty to "protect the population from religious sects" (Article 21). In fact, this article has become a formal basis for struggle against "infidels", primarily the representatives of Protestant churches and other Orthodox churches of the non-Moscow Patriarchate.

Just after the occupation, terrorists began systematic violence on representatives of the non-Moscow Patriarchate believers (kidnappings, torture and murders of priests, alienation of property (land, buildings, facilities etc.), suppression of financial records of religious organizations, prohibition of worship services, intimidation, etc.) ${ }^{39}$. Some of those crimes (in the liberated territories) are still under investigation, but in the occupied territories the rights and lives of many believers are under threat.

And finally, last but not least, is the issue of national security, which Ukraine faced after successful attempts to use the Orthodox Church as a factor of destabilization in the country. Until recently, this question has been given insufficient attention. The anti-state statements and dictums of some priests, their blessing of the terrorists and their weapons, participation in terrorist groups ${ }^{40}$ and the calls of some churches and mass media for violation of the territorial integrity of Ukraine (e.g., newspapers "The Triedinaia Rus", "The Novorossiyskii Courier", etc.) should become the subjects of legal investigation.

Many of these crimes have been ignored by law enforcement authorities. The experience of the last few years shows that the development of special mechanisms of reaction to such activities is an issue of the state agenda. Anyway religion should not be the reason for discrimination, but at the same time, today it is obvious that it can not also be an excuse to avoid responsibility for criminal actions.

37 Konstitutsiya Donetskoy Narodnoy Respubliki 14.05.2014 g. [The Constitution of the Donetsk People's Republic]. http://dnr-online.ru/konstituciya-dnr/ (20.06.2015).

38 Ibidem.

39 For more information on these crimes, see: Center for Civil Liberties, International Partnership for Human Rights, April 2015, "When God Becomes the Weapon. Persecution based on religious beliefs in the armed conflict in Eastern Ukraine”, 21 p. At: http://ccl.org.ua/wp-content/up loads/2013/07/When-God-Becomes-The-Weapon_6May2015_closed-for-editing.pdf (20.06.2015).

40 Ibidem, p. 11-12. 


\section{Conclusions}

One Russian politician once said that Ukraine had never been number one in Russian interests, but at the same time, it had never been less important. I think this formula can be used to describe the role of religion in the area of the East and South of Ukraine since spring 2014.

On the one hand, this is not a religious war. At least, Ukrainian religious organizations have repeatedly stated ${ }^{41}$ the inadmissibility of the use of religious rhetoric in those events. On the other hand, the armed conflict between Russia and Ukraine, which most Ukrainians perceive as an "aggressive war of Russia against Ukraine" 42 , is connected with religion. The religious factor was used at different stages of the conflict, although each party treats the fact of its involvement in a different way.

Despite the refusal to imply the religious factor, Ukrainian religious organizations are an important element of Ukrainian society. The fact that our country is in a state of war could not affect the religious life of Ukraine. These impacts have different forms and manifestations. The most significant trends were some changes in the religious self-identification of Ukrainians, which are clearly demonstrated by the latest sociological studies. The "parade of conversions" has become one of the external manifestations of these changes. The intensification of the search for new ways and forms of church unity and broad social cooperation is very important in the face of new military threats looming over Ukraine.

These changes have put several challenges to Ukraine. The first challenge refers to further work in the area of religious freedom and development of mechanisms of its practical implementation. At the same time, the new experience of warfare, which Ukraine faced for the first time, has put on the agenda a number of issues on national security, including the role of religion in national security and national defence, which is of great importance.

\footnotetext{
41 Vseukrayinska Rada Tserkov i relihiynykh orhanizatsiy, June 2014, "Zayava shchodo posyahan na svobodu virospovidannya ta sprob rozpalennya mizhkonfesiynoyi vorozhnechi" [Statement on the attacks on freedom of religion and attempts of incitement to religious hatred]. http://vrciro.org.ua/ua/statements/397-uccro-statement-religious-freedom (15.05.2015).

42 Tsentr Razumkova, 2015, "Otsinka hromadyanamy sytuatsiyi na Donbasi” [Assessment of the situation in Donbas], p. 3. At: http://www.uceps.org/upload/1428048471_file.pdf (15.05.2015).
} 


\section{The Impact of the Russian-Ukrainian Military Conflict on Religious Life in Ukraine}

\section{Summary}

The article investigates changes in the religious sphere of Ukraine since the beginning of the military conflict in Donetsk and Luhansk regions. The use of religious rhetoric to justify the annexation of the Crimea and to invade part of the Ukrainian territory has caused a serious shift in the religious self-identification of a considerable number of Ukrainians. These changes are manifested at several levels. On the personal level there was the reorientation of the most faithful to the pro-Ukrainian religious organizations or to the rejection of religion in general. At the institutional level there was an ambivalent effect. On the one hand, it triggered a series of parish conversions that caused new religious conflicts. On the other hand, it intensified the search for ways to consolidate Ukrainian churches. All these changes put on the agenda of Ukraine several challenges related to the defence of religious rights and freedom and defence of national security. The article is based on various sources produced by churches and their leaders, latest sociological data, and reports of human rights organizations and religious studies institutions.

Key words: Eastern Orthodoxy, Ukraine, Russian-Ukrainian War, religious selfidentification, religious conflicts, religious freedom

\section{References}

Casanova J., Between Nation and Civil Society: Ethnolinguistic and Religious Pluralism in Independent Ukraine, [in:] Democratic Civility: The History and Cross-Cultural Possibility of a Modern Political Ideal, ed. by R. Hefner, New Brunswick, NJ 1998, pp. 203-228, At: http://repository.berkleycenter.georgetown. edu/980201CasanovaBetweenNationCivilSocietyEthnolinguisticReligiousPluralis mIndependentUkraine.pdf

Center for Civil Liberties, International Partnership for Human Rights, April 2015, "When God Becomes the Weapon. Persecution based on religious beliefs in the armed conflict in Eastern Ukraine”, 21 p. At: http://ccl.org.ua/wp-content/uploads /2013/07/When-God-Becomes-The-Weapon_6May2015_closed-for-editing.pdf

Elenskii V., Ukrainian Orthodoxy and the Ukrainian Project. The Churches and "Unforeseen Statehood" in the Age of Religious Revival, "Russian Politics and Law", 2014, vol. 52, issue 4, pp. 7-33.

Greeley A. M., The Denominational Society: A Sociological Approach to Religion in America, Glenview, IL 1972, 266 p. 
Kongress natsional'nykh obshchin Ukrainy, 2014, “Ksenofobiya v Ukraine v 2014 g. na fone revolyutsii $i$ interventsii: Informatsionno-analiticheskiy doklad po rezultatam monitoringa" [Xenophobia in Ukraine in 2014 amid revolution and intervention: Information-analytical report on the monitoring results], p. 65. At: http://eajc.org/data//file/Xenophobia_in_Ukraine_2014.pdf

Konstitutsiya Donetskoy Narodnoy Respubliki 14.05.2014 g. [The Constitution of the Donetsk People's Republic]. http://dnr-online.ru/konstituciya-dnr/

Lunkin R., The Ukrainian Revolution and the Christian Churches, "East-West Ministry", 2014, Report 22, no. 3, pp. 1-6.

Maydan i Tserkva: Khronika podiy ta ekspertna otsinka [Maidan and the Church: Chronicle of Events and Expert Evaluation], red. L. Fylypovych, O. Horkusha, Kyiv $2015,650 \mathrm{~s}$.

Mead S. E., Denominationalism: The Shape of Protestantism in America, "Church History", 1954, vol. 23, nr. 4, pp. 291-320.

Memorandum pro yedynu Ukrayinu ta yedynu Ukrayinsku Pomisnu Pravoslavnu Tser$k v u$ [Memorandum on the unified Ukraine and the united Ukrainian Autocephalous Orthodox Church]. http://orthodoxy.org.ua/data/na-rivnenshchini-pidpisali-memo randum-pro-iedinu-ukrayinu-ta-iedinu-ukrayinsku-pomisnu

Ministerstvo kul'tury Ukrayiny, 2015, “Relihiyni orhanizatsiyi v Ukrayini (stanom na 1 sichnya 2015 r.)” [Religious Organizations in Ukraine (on January 1, 2015)]. http://risu.org.ua/ua/index/resourses/statistics/ukr2015/60129/

Mizhnarodnyy tsentr perspektyvnykh doslidzhen', Fond Demokratychni initsiatyvy imeni Il'ka Kucheriva, Kviten' 2015, “Tserkva v Ukrayini: element roz'yednannya, ob'yednannya chy myrotvorchosti? Rezul'taty zahal'nonatsional'noho sotsiolohichnoho opytuvannya, provedenoho u ramkakh proektu "Natsional'nyy dialoh" [The Church in Ukraine: an element of disintegration, integration, or peacemaking? Results of national poll conducted in terms of "Initiating the Participatory National Dialogue in Ukraine" project"], 9 p. At: http://icps.com.ua/assets/ uploads/files/national_dialogue_opinion_poll_3_part_ua.pdf

Obrashcheniye Svyateyshego Patriarkha Kirilla $k$ Predstoyatelyam Pomestnykh Pravoslavnykh Tserkvey $v$ svyazi s situatsiyey na Ukraine (24 avgusta 2014). [Address of His Holiness Patriarch Kirill to the Primates of Autocephalous Orthodox Churches on the situation in Ukraine (August 24, 2014)]. At: http://www.patriar chia.ru/db/text/3704024.html

Office of the United Nations High Commissioner for Human Rights. "Report on the human rights situation in Ukraine (16 February to 15 May 2015)”, 38 p. At: http:// www.ohchr.org/Documents/Countries/UA/10thOHCHRreportUkraine.pdf

Pew Research Center, January 2014, “Religious Hostilities Reach Six-Year High”, 90 p., At: http://www.pewforum.org/files/2014/01/RestrictionsV-full-report.pdf

Predsedatel departamenta po delam religiy ministerstva kultury Ukrainy Andrey Yurash o svoyei novoi dolzhnosti, yazykovoi $i$ religioznoi politike, izmeneniyakh v UPTS MP, situatsii v Krymu $i$ "DNR" [Chairman of the Department of Religious Affairs of the Ministry of Culture of Ukraine Andriy Yurash on his new role, 
linguistic and religious policies, changes in the UOC MP, the situation in Crimea and "DPR"], besedoval Vladimir Oyvin, "Portal-credo.ru". At: http://www.portalcredo.ru: $12000 /$ site/?act $=$ news\&id= 111867

Proekt Deklaratsiyi pro hidnist, svobodu i prava liudyny [The Draft of Declaration on Dignity, Freedom and Human Rights], Verkhovna Rada Ukrainy, 2010, 8 s. At: http://w1.c1.rada.gov.ua/pls/zweb2/webproc34?id=\&pf3511=38408\&pf35401=17 1219

Sahan O., Relihiyni hromady peretvoryly na "prypysnykh kripakiv" [Religious communities have turned into "bonded serfs"], 2015. At: http://risu.org.ua/ua/index/ expert_thought//comments//59594//

The UN Refugee Agency, June 2015, “Ukraine: Internally Displaced People” (June 22, 2015). At: http://unhcr.org.ua/attachments/article/1244/map47.jpg

Tsentr Razumkova, 2015, “Otsinka hromadyanamy sytuatsiyi na Donbasi” [Assessment of the situation in Donbas], 6 p. At: http://www.uceps.org/upload/1428048471_ file.pdf

Tsentr Razumkova, Lystopad 2010, “Z yakoyu otsinkoyu stavlennya derzhavnoyi vlady do Tserkov v Ukrayini Vy zhodni naybil'shoyu miroyu?" [What government attitude to Churches in Ukraine do you accept?]. At: http://www.uceps.org/ukr/poll.php? poll_id=689

Tsentr sotsial'nykh ta marketynhovykh doslidzhen' SOCIS, and et al., Kviten' 2015, “Relihiyni vpodobannya naselennya Ukrayiny" [Religious preferences of the population of Ukraine], 8 p. At: http://www.ratinggroup.com.ua/upload/files/RG_religion_ report_042015.2.pdf

Ukrayins'ka Pravoslavna Tserkva Kyyivs'koho Patriarkhatu, Ukrayins'ka Avtokefal'na Pravoslavna Tserkva, Cherven' 8, 2015, "Pidsumkove rishennya spil'noho zasidannya Komisiy dlya vedennya dialohu" [Final decision of the meeting of the Committees for dialogue], 3 s. At: http://www.cerkva.info/uk/publications/ articles/6958-rishennia.html

United States Commission on International Religious Freedom. Annual Report 2015, 232 p. At: http://www.uscirf.gov/sites/default/files/USCIRF\%20Annual\%20Repo rt\%202015\%20(2).pdf

Vasin M., Donbas i Krym: novi vyklyky dlya relihiynoyi svobody. Pidsumky roku [Donbass and Crimea: new challenges for religious freedom. Results of the year]. At: http://risu.org.ua/ua/index/expert_thought/analytic/58577/

Vidkrytyy lyst Predstoyatelyu UPTS mytropolytu Onufriyu vid hromady Dymytriyivskoho khramu sela Vyshniv [Open letter of the community of the church of St. Dmytriy in the village of Vyshniv to Metropolitan Onuphrius]. http://vyshniv.blogspot.com/ 2014/10/blog-post_8.html

Vseukrayinska Rada Tserkov i relihiynykh orhanizatsiy, June 2014, "Zayava shchodo posyahan na svobodu virospovidannya ta sprob rozpalennya mizhkonfesiynoyi vorozhnechi" [Statement on the attacks on freedom of religion and attempts of incitement to religious hatred]. http://vrciro.org.ua/ua/statements/397-uccrostatement-religious-freedom 
Yelensky V., Religion and Human Rights: The Case of Ukraine, [in:] Religion and Human Rights. An International Perspective, ed. by H.-G. Ziebertz and G. Črpić, Cham 2015, pp. 195-206.

ZN.UA, Kyyivs'kyy mizhnarodnyy instytut sotsiolohiyi, "Mneniya $i$ vzglyady naseleniya Ukrainy: Dekabr 2014 goda" [The views and opinions of the Ukrainian population: December 2014]. At: http://opros2014.zn.ua/authority

Zvernennya hromady tserkvy Iverskoyi Bozhoyi Materi v seli Kruholets Ternopilskoyi yeparkhiyi UPTS (Moskovskoho Patriarkhatu) do Predstoyatelya UPTS mytropolyta Onufriya [Appeal of the Community of the Church of the Iberian Icon of the Mother of God in the village of Kruholets in Ternopil Eparchy (Moscow Patriarchate) to the Primate of the Ukrainian Orthodox Church Metropolitan Onuphrius], http://www.religion.in.ua/news/ukrainian_news//28129-mi-svyashheniki-upc-opini lisya-mizh-gorem-svogo-narodu-i-vorozhoyu-poziciyeyu-patriarxiyi-ternopilska-g romada-upc-napisala-vidkrite-zvernennya-mitropolitu-onufriyu.html 